\title{
Short-Term Effects of Changing Soil Management Practices on Soil Quality Indicators and Crop Yields in Greenhouses
}

\author{
Jerónimo Salinas ${ }^{1, * \mathbb{D}}$, David Meca ${ }^{2}$ and Fernando del Moral ${ }^{1}$ (D) \\ 1 Department of Agronomy, University of Almería, Agrifood Campus of International Excellence ceiA3, \\ Ctra, Sacramento s/n, 04120 Almería, Spain; fmoral@ual.es \\ 2 Cajamar Research Station, Cajamar Foundation, Grupo Cooperativo Cajamar, Paraje Las Palmerillas 25, \\ 04710 El Ejido, Almería, Spain; daviderikmeca@fundacioncajamar.com \\ * Correspondence: jerosalinasr@gmail.com; Tel.: +34-950-015924
}

Received: 19 March 2020; Accepted: 16 April 2020; Published: 18 April 2020

\begin{abstract}
The short-term responses of soil quality indicators are important for assessing the effects of new management practices and addressing threats to crop yields in greenhouses. The aim of this study was to assess, during three consecutive cropping seasons, the effect of a sustainable management package (CRTMP) — which includes the on-site reuse of greenhouse crop residues and tillage-in comparison with conventional management, based on fertigation only (CMP), on certain biochemical soil quality indicators and crop yields. CRTMP significantly increased $(p<0.05)$ the values of total organic carbon (TOC), particulate organic carbon (POC), light fraction (LF), water soluble organic carbon (WSOC), and dehydrogenase (DH) and $\beta$-glucosidase (GL) activities at a depth of $0-15 \mathrm{~cm}$, as well as the mean concentration of nitrates in the soil solution. In addition, a significant Pearson's correlation $(p<0.01)$ found between the indicators suggested a balanced improvement of soil biological activity and nutritional soil state. Nonetheless, the significant $(p<0.05)$ increases in the mean concentration of chlorides in the soil solution and electrical conductivity $(p<0.05)$ increased the risk of salinization, which may have affected the concentration of nitrates in the petiole sap and total production in CRTMP, which were significantly lower than in CMP. Nevertheless, the proportion of premium product was significantly higher in CRTMP, while the proportion of non-commercial production decreased.
\end{abstract}

Keywords: organic carbon fractions; soil enzymes; crop management; soil solution

\section{Introduction}

Greenhouse agriculture, based on production and profitability, is becoming widespread in the Mediterranean region, with an increasing socioeconomic impact [1]. The province of Almeria (SE Spain), with 31,034 ha, has the highest concentration of greenhouses, most of which are low or medium cost structures with plastic covers [2,3], dedicated to the cultivation of horticultural species. Conventional greenhouse management practices are characterized, in most cases, by the excessive use of agrochemicals and irrigation water $[4,5]$, which, along with the absence of organic inputs or tillage, tends to make the soil lose quality in the long term [6-9] and has caused a series of environmental problems associated with nitrate leaching $[10,11]$ or with the accumulation of a huge amount of crop residues at the end of the cropping season [12]. These problems, coupled with the current situation of the instability of prices perceived by the farmers, which sometimes do not cover production costs [1], endanger the future sustainability of the system.

It is, therefore, becoming necessary to introduce alternative management packages that will enable the system to reduce its dependence on external inputs [12], while optimizing resources and reducing 
waste generation $[8,13]$, mainly crop residues. However, agricultural greenhouse systems demand high investments per crop season that need to be compensated with income in a very short period of time; therefore, it is particularly important to carefully select indicators that allow, in the short term, an accurate assessment of the impact of new management practices on soil and crops. Several studies in outdoor and greenhouse farming have shown that the contribution of organic materials can cause significant changes in biochemical properties and alter microbial activity, improving soil quality [14-17], and has been used to meet the $\mathrm{N}$ demands of the crops [18]. Del Moral et al. [19], after a long-term trial, demonstrated that several soil physical properties were improved in organic managed greenhouses fertilized with manure, and that total organic carbon, total nitrogen and the cation exchange capacity were increased in comparison with conventional management. However, for the correct management of intensive crops in greenhouses, more information regarding the evolution of different soil quality indicators during cultivation and their impact on the harvest is necessary, covering the existing scientific information deficit for this agrosystem, while providing useful and convincing information to stakeholders.

Soil quality indicators provide information on the properties, characteristics and processes related to the soil functions and soil fertility [20-23]. Among them, biochemical indicators, because of their high sensitivity in short term, could be useful to assess the impact of any new management practice.

Although total organic carbon is the most widely used indicator to assess soil quality, soil productivity and agricultural sustainability $[24,25]$, it is generally accepted that the change in its content is not very sensitive in the short and medium term [26,27], so labile fractions-which often include particulate organic carbon (POC), light fraction (LF), and water-soluble organic carbon (WSOC) [28] - have been used as short-term indicators after changing soil management practices [29-34]. POC, LF and WSOC are three fractions considered active in the nutrient cycles, readily available for microbial breakdown and closely associated with nutrient supply to crops [35,36].

Enzymatic activities are also widely used indicators for their sensitivity to management change in agricultural systems, and provide information about soil microbial activity and biomass, the decomposition of organic matter, nutrient cycling, nutrient availability to crops, and other soil properties [37-42]. Among them, dehydrogenase (DH) and $\beta$-glucosidase (GL) are two frequently monitored enzymes $[43,44]$. DH activity, associated with the active fraction of the soil microbial community [45], reflects recent management or seasonal effects [46,47]; GL catalyzes the final step in the biodegradation of cellulose $[48,49]$ and has been found to be sensitive to soil management, with changes being detectable within 1-3 years [50]. Finally, electrical conductivity (EC) is a frequently used indicator to assess the soil salinization risk [51], and periodic soil solution nitrate analysis is important to assess the availability of $\mathrm{N}$ to crops in greenhouses soils [52]. In this sense, the accumulation of chlorides and nitrates in soil solution can increase soil electrical conductivity and be harmful to crops $[53,54]$.

The aim of this study was to assess the effects of a new management package—based on tillage, the use of crop residues and organic amendments with minimum inorganic fertilizer inputs-compared to a control with conventional management, during three consecutive cropping seasons, on the (i) short-term evolution of biochemical soil quality indicators, (ii) evolution of nitrate and chloride concentrations of the soil solution and (iii) crop yields in greenhouse systems.

\section{Materials and Methods}

\subsection{Location and Description of Greenhouses}

The experimental work was conducted during three consecutive cropping seasons (2015-2016, 2016-2017 and 2017-2018) in two adjacent and identical greenhouses (Greenhouse T0 and Greenhouse T1), built with the same artificial soil (Table 1) and having the same cultivation history, located in the Cajamar Experimental Station “Las Palmerillas", El Ejido, Almería, SE Spain $\left(36^{\circ} 48^{\prime} \mathrm{N}, 2^{\circ} 43^{\prime} \mathrm{W}\right.$ and $151 \mathrm{~m}$ elevation). The dimensions of each of them were $24 \mathrm{~m}$ long by $18 \mathrm{~m}$ wide, oriented 
East to West. The greenhouses had a height of $2.9 \mathrm{~m}$ on the sidebands and $4.2 \mathrm{~m}$ on the ridge. The covering of the greenhouses was low density polyethylene (LDPE) tri-laminated film (200 $\mu \mathrm{m}$ thickness). The greenhouses had passive ventilation through two roll-up side windows ( $2 \mathrm{~m}$ height $\mathrm{x}$ $22 \mathrm{~m}$ long) on the north and south sides, and a folding top window. All windows were covered by a $20 \times 10 \mathrm{~cm}^{2}$ insect screen and their opening and closing was controlled by an automatic controller (Priva WeatherStation, Priva, LC De Lier, The Netherlands).

Table 1. Soil properties of each greenhouse before starting the study at a depth in the $0-15 \mathrm{~cm}$ range.

\begin{tabular}{ccc}
\hline & Greenhouse T0 & Greenhouse T1 \\
\hline Soil Texture (USDA) & Silty clay loam & Silty clay loam \\
TOC & $6.21(1.10)$ & $6.47(1.48)$ \\
POC & $0.72(0.33)$ & $0.80(0.36)$ \\
WSOC & $0.05(0.01)$ & $0.06(0.01)$ \\
LF & $0.18(0.12)$ & $0.40(0.24)$ \\
DH & $2.46(0.96)$ & $2.84(1.07)$ \\
GL & $77.34(14.60)$ & $89.32(18.28)$ \\
TN & $1.10(0.35)$ & $1.70(0.40)$ \\
EC & $0.50(0.15)$ & $0.75(0.15)$ \\
pH & $8.49(0.04)$ & $8.45(0.04)$ \\
\hline
\end{tabular}

The data show values from five samples obtained in randomly selected crop lines in each greenhouse. There were no significant differences in soil properties $(p<0.05)$, according to Mann-Whitney U test. TOC: total organic carbon ( $\mathrm{g} \mathrm{kg}^{-1}$ soil); POC: particulate organic carbon ( $\mathrm{g} \mathrm{kg}^{-1}$ soil); WSOC: water-soluble organic carbon ( $\mathrm{g} \mathrm{kg}^{-1} \mathrm{soil}$; LF: light fraction ( $\mathrm{g} \mathrm{kg}^{-1}$ soil); DH: dehydrogenase activity ( $\mathrm{mg} \mathrm{TPF} \mathrm{kg}^{-1}$ soil day-1); GL: $\beta$-glucosidase activity ( $\mu$ mol PNG kg ${ }^{-1}$ soil $\left.\mathrm{h}^{-1}\right)$; TN: total nitrogen ( $\mathrm{g} \mathrm{kg}^{-1}$ soil); EC: electrical conductivity $\left(\mathrm{dS} \mathrm{m}^{-1}\right)$. EC and $\mathrm{pH}$ were determined in a 1:5 solution (v/v soil/water).

The irrigation system consisted of two independent irrigation sectors for each greenhouse, regulated with a flow meter (COTHINDRA, JANZ Group, CU 2520), with 24 paired dripper lines per sector and 16 integrated self-compensating drippers per line (Netafim, Tel Aviv, Israel), with a flow rate of $3.1 \mathrm{~L} \mathrm{~h}^{-1}$. The distances were $1.5 \mathrm{~m}$ between the dripper lines (corridor), $0.5 \mathrm{~m}$ between the paired lines and $0.4 \mathrm{~m}$ between the drippers. The electrical conductivity $(\mathrm{EC})$ of the irrigation water was $1.6 \mathrm{dS} \mathrm{m}^{-1}$ (Table 2), and the irrigation doses and frequencies were calculated with the PrHo program (C) Cajamar Foundation) in order to reproduce irrigation similar to that achieved by the farmers in the area. Drainage was collected using two replicate free-draining lysimeters $(4 \mathrm{~m}$ long $\times 2 \mathrm{~m}$ wide $\times 0.6 \mathrm{~m}$ deep) located at the southern side of each greenhouse.

Table 2. Average ion concentrations for irrigation water and nutrient solutions $\left(\mathrm{mmol} \mathrm{L}^{-1}\right)$.

\begin{tabular}{cccc}
\hline & Water & CMP & CRTMP \\
\hline $\mathrm{NO}_{3}{ }^{-}$ & 0.15 & 11.02 & 3.49 \\
$\mathrm{H}_{2} \mathrm{PO}_{4}^{-}$ & 0.00 & 1.56 & 0.00 \\
$\mathrm{SO}_{4}{ }^{-}$ & 0.48 & 1.59 & 0.48 \\
$\mathrm{Cl}^{-}$ & 9.81 & 9.81 & 9.81 \\
$\mathrm{HCO}_{3}{ }^{-}$ & 2.50 & 2.50 & 2.50 \\
$\mathrm{NH}_{4}^{+}$ & 0.00 & 0.19 & 0.00 \\
$\mathrm{~K}^{+}$ & 0.14 & 6.24 & 0.14 \\
$\mathrm{Ca}^{++}$ & 2.23 & 4.84 & 2.77 \\
$\mathrm{Mg}^{++}$ & 2.05 & 2.23 & 2.05 \\
$\mathrm{Na}^{+}$ & 4.73 & 4.73 & 4.73 \\
\hline
\end{tabular}

\subsection{Description of Soil Management Packages}

Greenhouse T0: conventional management package (CMP) or control. The distribution of soil horizons was the most common in the greenhouses in Almeria: from top to bottom, a coarse river sand layer as inorganic mulching (0-10 cm depth), silty clay loam soil layer imported from quarry $(10-40 \mathrm{~cm}$ 
depth) and sandy clay loam original soil ( $>40 \mathrm{~cm}$ depth). Fertilization and irrigation were similar to those in the commercial greenhouses in the area (fertigation) (Tables 2 and 3). The accumulated total nitrogen supplied in the form of inorganic fertilizers, in accordance with local practice regarding the typical $\mathrm{N}$ concentration used in fertigation of the sweet pepper, for the whole of the three cropping seasons, was $196.09 \mathrm{~g} \mathrm{~m}^{-2}$. No crop residues or organic fertilizers were provided, nor was any tillage carried out. The total water contributed throughout the three cropping seasons was $1250.12 \mathrm{~L} \mathrm{~m}^{-2}$. The total drainage collected was $308.91 \mathrm{~L} \mathrm{~m}^{-2}$.

Table 3. The total amount of inorganic fertilizer provided in each management package for all three growing seasons $\left(\mathrm{kg} \mathrm{ha}^{-1}\right)$.

\begin{tabular}{ccc}
\hline & CMP & CRTMP \\
\hline $\mathrm{Ca}\left(\mathrm{NO}_{3}\right)_{2}$ & 7690 & 1473 \\
$\mathrm{HNO}_{3}$ & 2202 & 1658 \\
$\mathrm{KNO}_{3}$ & 3613 & 0 \\
$\mathrm{~K}_{2} \mathrm{SO}_{4}$ & 2043 & 0 \\
$\mathrm{MgSO}_{4}$ & 540 & 0 \\
$\mathrm{KH}_{2} \mathrm{PO}_{4}$ & 2325 & 0 \\
$\mathrm{NH}_{4} \mathrm{H}_{2} \mathrm{PO}_{4}$ & 273 & 0 \\
\hline
\end{tabular}

Greenhouse T1: alternative management package based on the incorporation of crop residues, organic fertilizers and tillage (CRTMP), with the minimum use of inorganic fertilizers. In each cropping season, the soil was tilled to a depth of approximately $40 \mathrm{~cm}$, with two cross passes using a rigid five double coil tines chisel powered by a Pasquali Siena K5.60 tractor. Then, organic amendments were added (Table 4): $2 \mathrm{~kg} \mathrm{~m}^{-2}$ (fresh weight) of chopped sweet pepper crop residues from previous crop seasons and $2.5 \mathrm{~kg} \mathrm{~m}^{-2}$ (fresh weight) of organic fertilizers (in the form of compost of horticultural crops $(25 \%)$ and manure $(75 \%))$. The organic amendments were mixed at a depth of $15 \mathrm{~cm}$ using a self-propelled two-wheel cultivator (Pasquali 10.0 ZR, BCS Ibérica SAU, Terrasa, Spain). The estimated total nitrogen supplied in the form of crop residues and organic fertilizers throughout the three cropping seasons was $120.67 \mathrm{~g} \mathrm{~m}^{-2}$ (Table 5). The total nitrogen supplied in the form of inorganic fertilizers throughout the three cropping seasons was $56.63 \mathrm{~g} \mathrm{~m}^{-2}$ (Table 3). The inorganic fertilizer was applied to approximately equalize nitrogen inputs between the management packages. The total water contributed throughout the three cropping seasons was $1160.71 \mathrm{~L} \mathrm{~m}^{-2}$. The total drainage collected was $170.06 \mathrm{~L} \mathrm{~m}^{-2}$.

Table 4. The mean composition of the organic amendments applied to the soil at the beginning of the study in the sustainable management package (CRTMP).

\begin{tabular}{cccccccc}
\hline & & $\begin{array}{c}\text { Bulk } \\
\text { Density }\end{array}$ & TOC & TN & EC & pH & {$\left[\mathbf{C l}^{-}\right]$} \\
\hline \multirow{2}{*}{$\begin{array}{c}\text { Organic } \\
\text { amendments }\end{array}$} & Compost & $0.48(0.02)$ & $\begin{array}{c}210.40 \\
(15.20)\end{array}$ & $18.00(0.40)$ & $28.10(2.30)$ & $7.71(0.01)$ & $35.40(2.40)$ \\
& Manure & $0.40(0.01)$ & $\begin{array}{c}241.70 \\
(14.15)\end{array}$ & $20.00(0.18)$ & $12.87(1.12)$ & $9.51(0.01)$ & $16.20(1.50)$ \\
& Crop residues & $0.56(0.01)$ & $\begin{array}{c}307.20 \\
(19.00)\end{array}$ & $13.90(0.20)$ & $18.40(1.10)$ & $9.52(0.01)$ & $7.80(0.75)$ \\
\hline
\end{tabular}

Bulk density was measured over fresh organic amendments $\left(\mathrm{g} \mathrm{cm}^{-3}\right)$. TOC: total organic carbon $\left(\mathrm{g} \mathrm{kg}^{-1}\right.$ dry weight); TN: total nitrogen $\left(\mathrm{g} \mathrm{kg}^{-1}\right.$ dry weight); EC: electrical conductivity $\left(\mathrm{dS} \mathrm{m}^{-1}\right) ;\left[\mathrm{Cl}^{-}\right]$: chloride concentration $\left(\mathrm{g} \mathrm{kg}^{-1}\right)$. $\mathrm{EC}$ and $\mathrm{pH}$ were determined in a 1:5 solution (v/v organic amendment/water). Standard deviations are shown in brackets $(n=3)$. 
Table 5. Top: the total amount (over dry weight), total nitrogen and total organic carbon addition of crop residues and organic amendments $\left(\mathrm{g} \mathrm{m}^{-2}\right)$ in CRTMP for all three cropping seasons. Bottom: the crop varieties, date of transplant and date of crop removal in each cropping season.

\begin{tabular}{|c|c|c|c|c|c|}
\hline & & Amount & TN Input & & TOC Input \\
\hline \multicolumn{2}{|c|}{ Crop residues } & 1320 & 18.35 & & 405.50 \\
\hline Organic & Compost & 1240 & 22.32 & & 260.90 \\
\hline fertilizers & Manure & 4000 & 80.00 & & 966.80 \\
\hline \multirow{3}{*}{\multicolumn{2}{|c|}{ TOTAL }} & & 120.67 & & 1633.20 \\
\hline & & \multicolumn{4}{|c|}{ Crop Season } \\
\hline & & 2015-2016 & & 2016-2017 & $2017-2018$ \\
\hline Crop & ieties & Ebro & & Canción & Melchor \\
\hline Date o & asplant & 09/18/2015 & & 07/28/2016 & 08/03/2017 \\
\hline Date of & removal & 05/03/2016 & & 03/08/2017 & 04/09/2018 \\
\hline
\end{tabular}

\subsection{Description of the Crop Management}

For each cropping season, after soil preparation, individual 5 week old seedlings of sweet pepper (Capsicum annuum L.) were transplanted at 6-8 $\mathrm{cm}$ from each dripper with a planting density of 2.4 plants $\mathrm{m}^{-2}$. The crop varieties used and the dates of the transplant and crop removal are shown in Table 5. The crop management practices (crop training, pruning, pest management, etc.) in both greenhouses, apart from the soil management packages, were the same and followed the established local practice.

\subsection{Soil Sampling}

Five lines were randomly selected in each greenhouse, every month of each cropping season. From each selected line, three drippers were randomly selected, in each of which a soil subsample was taken at $0-15 \mathrm{~cm}$ depth to be mixed in a composite sample per line. In total, there were 135 composite samples per greenhouse. The subsamples were collected with an auger of $4.5 \mathrm{~cm}$ internal diameter, $10 \mathrm{~cm}$ from the dripper towards the corridor and avoiding the saline margin of the wet bulb, one day after irrigation. At the CMP, the sand mulch layer was removed before sampling. Once collected, the samples were kept field moist in polyethylene bags sealed at $4{ }^{\circ} \mathrm{C}$ until required.

\subsection{Soil Analyses}

Field moist samples were ground and sieved to $2 \mathrm{~mm}$. Part of the sample was air dried and stored at room temperature to determine the EC.

Total organic carbon (TOC, $\mathrm{g} \mathrm{kg}^{-1}$ soil) was determined in finely ground soil by wet oxidation [55]. POC was fractionated after dispersion of the sample with sodium hexametaphosphate and passing the sample through a 53 micrometer sieve [56]. LF was determined after density separation with potassium iodide (density $1.7 \mathrm{~g} \mathrm{~cm}^{-3}$ ), so that the heavy fraction was deposited on the bottom and LF floated on the surface [57]. WSOC was determined after the filtration of the soil/water solution (1:2) [58]. Dehydrogenase activity ( $\mathrm{DH}, \mathrm{mg}$ TPF $\mathrm{kg}^{-1}$ soil day ${ }^{-1}$ ) was measured following the procedures described by Neogi et al. [59], and $\beta$-glucosidase activity (GL, $\mu$ mol PNG kg-1 soil h${ }^{-1}$ ) was measured following the procedures described by Eivazi and Tabatabai [60]. For DH activity, the concentration of triphenyl formazan (TPF), resulting from the reduction of chloride from 2-3-5-triphenyltetrazolium (TTC), was determined by spectrophotometry at $485 \mathrm{~nm}$. GL activity was quantified based on the colorimetric measurement $(410 \mathrm{~nm})$ of $p$-nitrophenol released by $\beta$-glucosidase when the soil was incubated with a buffered solution of p-nitrophenyl- $\beta$-D-glucoside (PNG).

Electrical conductivity (EC, $\left.\mathrm{dS} \mathrm{m}^{-1}\right)$ was measured in soil [61] and organic amendments [62] in a 1:5 suspension (v/v), with a Crison 522 conductivity meter [63]. $\mathrm{pH}$ was measured in soil [64] and organic amendments [65] in a 1:5 suspension (v/v) with a Crison basic $20 \mathrm{pH}$-meter. The $\left[\mathrm{NO}_{3}{ }^{-}\right]$and $\left[\mathrm{Cl}^{-}\right]$ 
of soil solutions ( $\mathrm{mg} \mathrm{L}^{-1}$ ) were measured in 1:5 soil suspensions (soil/water) by ion chromatography (ICS-1000 Dionex, Thermo Scientific, Waltham, Massachusetts, USA).

\subsection{Measurements of Crop N Status}

The $\left[\mathrm{NO}_{3}{ }^{-}\right]$in petiole sap was analyzed every seven weeks throughout the cropping seasons. Six plants were randomly selected from the central crop lines in each greenhouse. The most recently expanded leaves of each of the six different plants in each management package were used; the petiole and fresh leaf blade were separated. Subsequently, the petioles of each plant were pressed, and the sap was obtained for analysis. The $\left[\mathrm{NO}_{3}{ }^{-}\right]$was determined by means of selective electrodes, LAQUAtwin (Horiba Instruments Incorporated. California USA) [66].

\subsection{Fruit Production}

Four replicate areas of $3.2 \mathrm{~m}^{2}$, each with eight plants, were used to determine the fruit production. There were at least nine fruit harvests during each pepper crop. The first harvest was always done in green, and the rest of the harvests in red. For each fruit harvest, the fruit fresh weight per plant was determined. Fresh production was separated into marketable, with two categories, and non-marketable, according to locally used commercial criteria.

\subsection{Statistical Analysis}

Differences between management packages were determined $(p<0.05)$, treating them as independent samples, by means of non-parametric methods (Mann-Whitney $U$ test), due to the lack of normality. Relationships between soil quality indicators were determined by Pearson's coefficient, and it was determined if this correlation was significant $(p<0.01)$. All statistical analyses were performed with the SPSS 25.0 and Excel software.

\section{Results}

\subsection{Effects of the Application of the Management Packages on Soil Quality Indicators}

The application of CRTMP significantly $(p<0.05)$ increased the values of all measured biochemical soil quality indicators in the $0-15 \mathrm{~cm}$ depth range, in which organic amendments and crop residues were added, except for WSOC at the beginning of the first two cropping seasons (Figure 1). These considerable increases were evident from the first cropping season in all measured indicators. In CRTMP, TOC had highest mean values at the beginning of the cropping seasons, after the recent tillage and incorporation of the organic amendments. The mean values of POC, LF and DH tended to increase during the second and third cropping seasons. In relation to GL, in CRTMP, values at the beginning of the first cropping season were lower than in the rest of the study, with the mean values established between $250.00 \pm 42.83$ and $342.75 \pm 77.68 \mu \mathrm{mol} \mathrm{PNG} \mathrm{kg}{ }^{-1}$ soil $^{-1}$. The variability of the mean values in CRTMP were higher than with the CMP management package.

In CRTMP, the mean percentages of POC and LF relative to TOC were considerably high $(38.5 \% \pm 13.4 \%$ and $16.0 \% \pm 6.3 \%$, respectively), being more than half, and higher than in CMP $(17.2 \% \pm 7.3 \%$ and $2.5 \% \pm 2.0 \%$, respectively); the mean percentages of WSOC relative to TOC were relatively low in CRTMP $(3.3 \% \pm 1.2 \%)$ and CMP $(2.4 \% \pm 2.2 \%)$. 


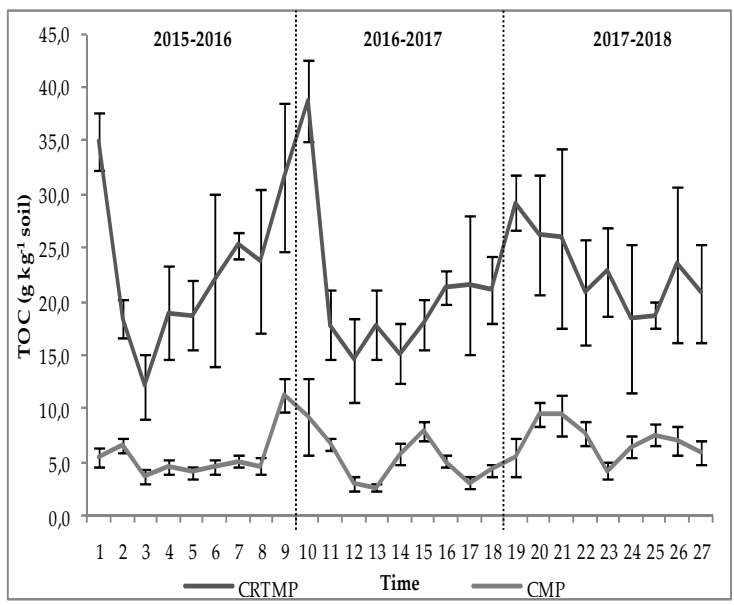

(a)

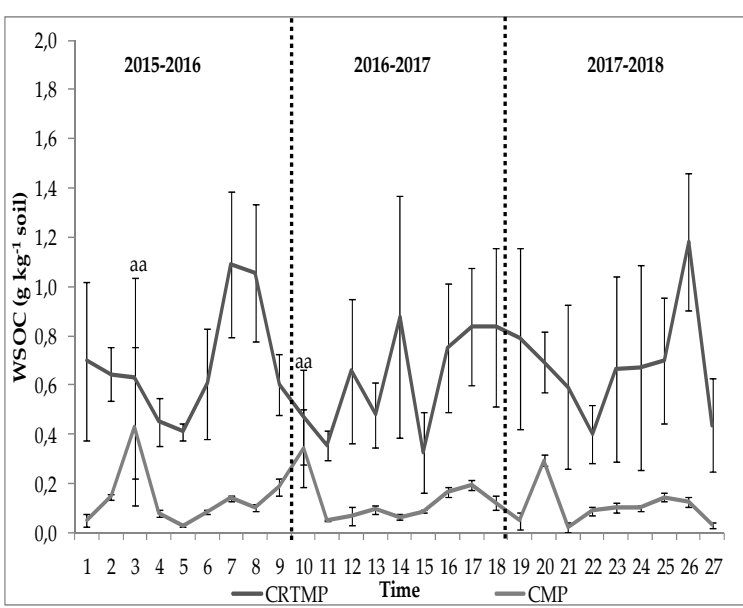

(c)

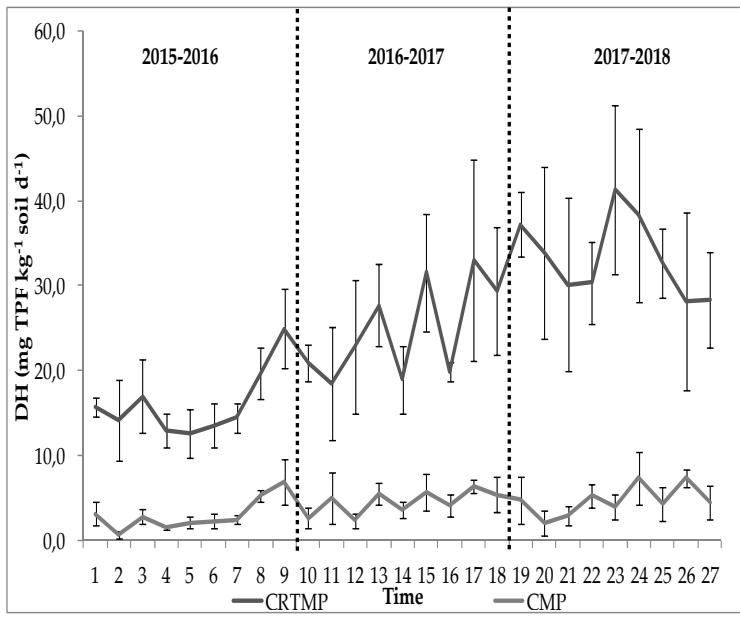

(e)

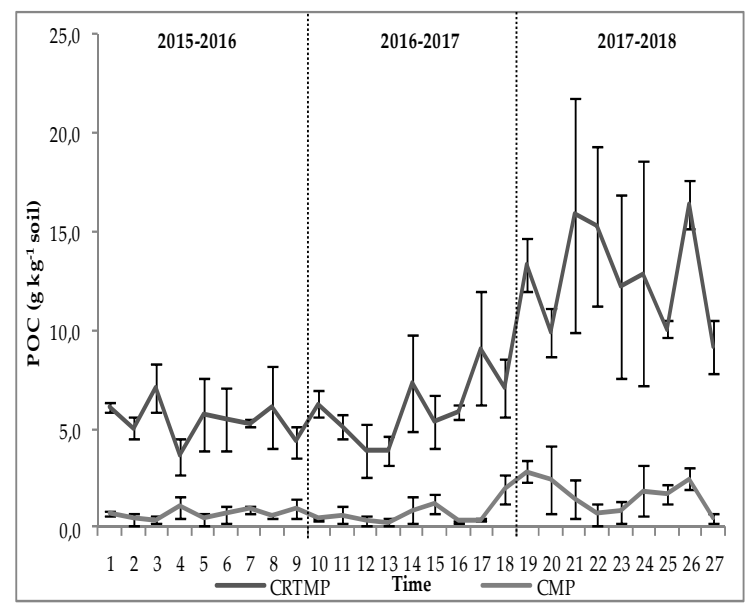

(b)

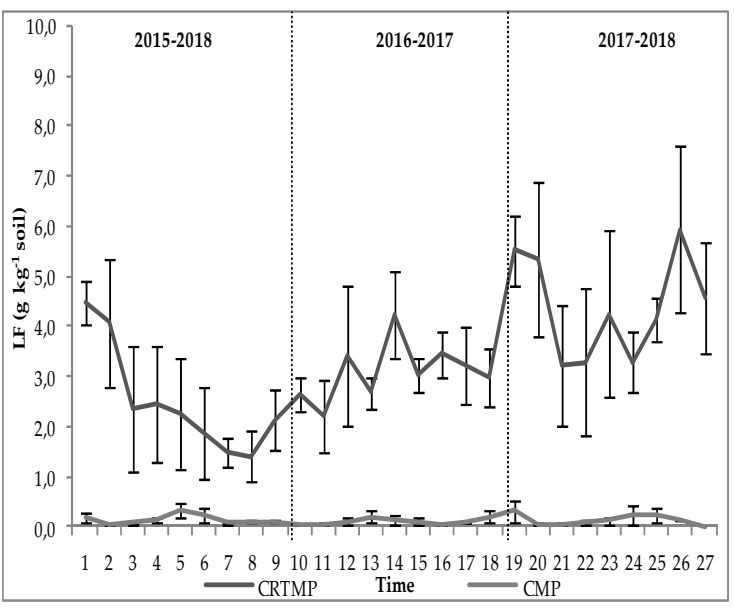

(d)

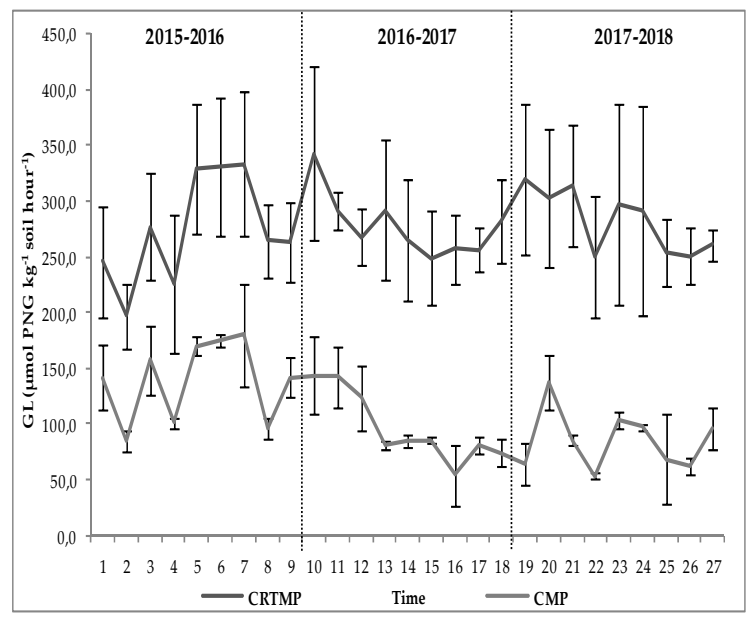

(f)

Figure 1. Growing season trends of (a) total organic carbon (TOC, $\mathrm{g} \mathrm{kg}^{-1}$ soil), (b) particulate organic carbon (POC, $\mathrm{g} \mathrm{kg}^{-1}$ soil), (c) water-soluble organic carbon (WSOC, $\mathrm{g} \mathrm{kg}^{-1}$ soil), (d) light fraction (LF, $\mathrm{g} \mathrm{kg}^{-1}$ soil), (e) dehydrogenase activity ( $\mathrm{DH}, \mathrm{mg} \mathrm{TPF} \mathrm{kg}^{-1}$ soil day ${ }^{-1}$ ), and (f) $\beta$-glucosidase activity (GL, $\mu$ mol PNG kg ${ }^{-1}$ soil $^{-1}$ ) in the two management packages (CMP and CRTMP) during the three study cropping seasons (2015-2016, 2016-2017 and 2017-2018). Values are means \pm SE. The same letters mean no significant differences $(p<0.05)$. The vertical dotted lines indicate the beginning of the cropping season and the incorporation of organic amendments. The correlative numbers on the $\mathrm{X}$-axis refer to the months that had passed, with cultivation, since the beginning of the trials. 


\subsection{Electrical Conductivity, $\left[\mathrm{Cl}^{-}\right]$and $\left[\mathrm{NO}_{3}^{-}\right]$of the Soil Solution}

The electrical conductivity, $\left[\mathrm{NO}_{3}{ }^{-}\right]$and $\left[\mathrm{Cl}^{-}\right]$of the soil solution in CRTMP were significantly higher than with the CMP management package (Figure 2). In CRTMP, the highest mean values were detected at the beginning of the cropping seasons, with the recent incorporation of organic amendments, especially in the first cropping season.

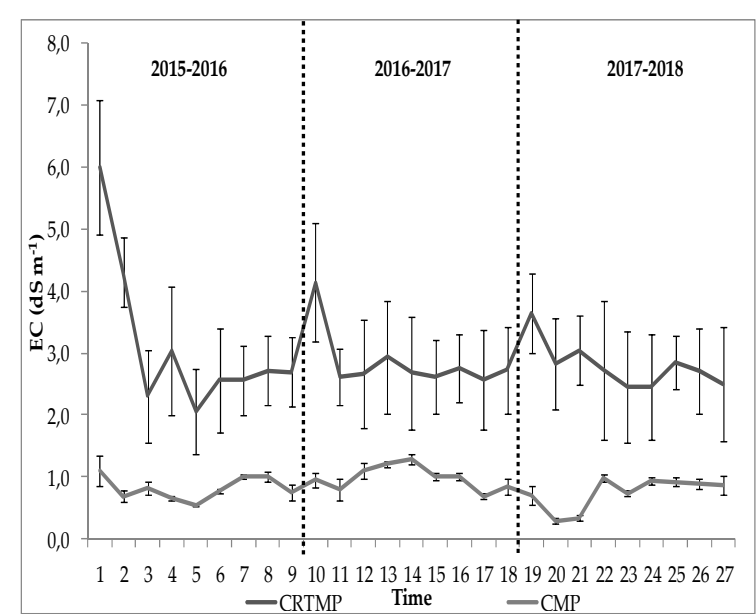

(a)

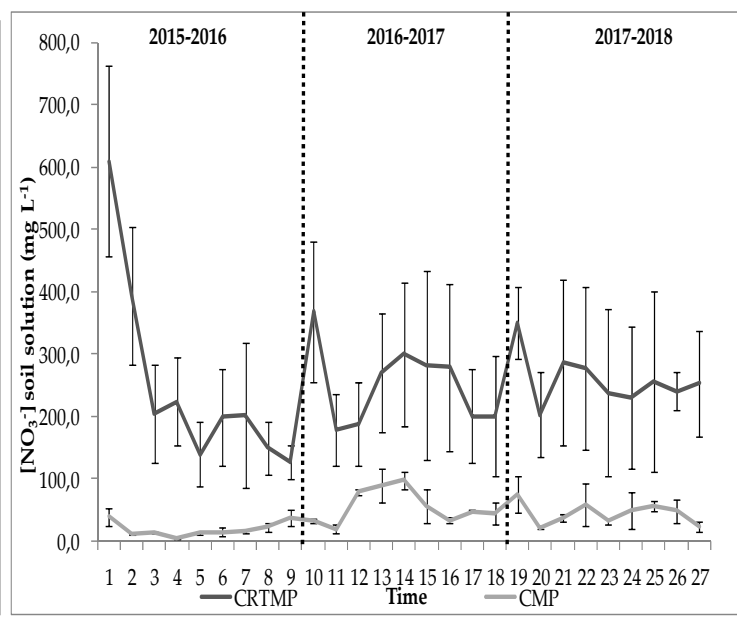

(b)

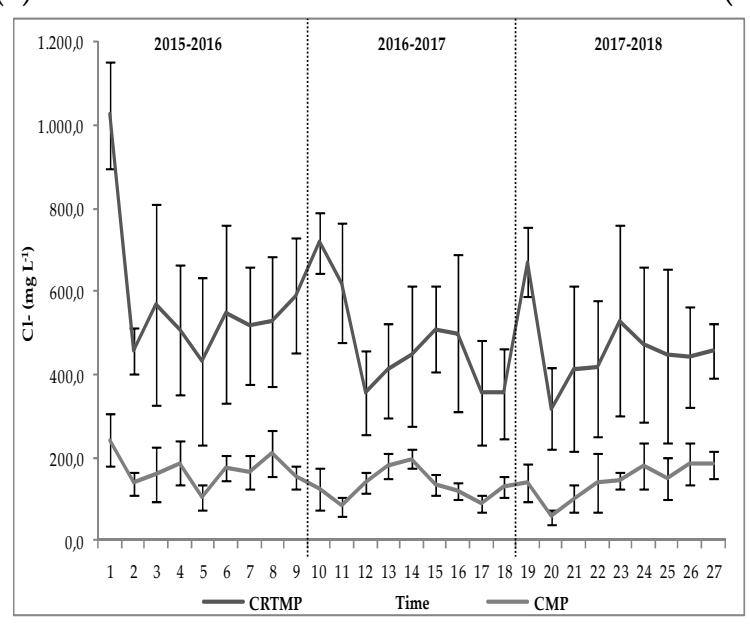

(c)

Figure 2. Growing season trends of (a) electrical conductivity $\left(\mathrm{EC}, \mathrm{dS} \mathrm{m}{ }^{-1}\right),(\mathbf{b})\left[\mathrm{NO}_{3}^{-}\right]$and (c) $\left[\mathrm{Cl}^{-}\right]$ of the soil solution in the two management packages (CMP and CRTMP) during the three study cropping seasons (2015-2016, 2016-2017 and 2017-2018). Values are means \pm SE. There were significant differences in all months $(p<0.05)$. The vertical dotted lines indicate the beginning of the cropping season and the incorporation of organic amendments. $\mathrm{EC},\left[\mathrm{NO}_{3}{ }^{-}\right]$and $\left[\mathrm{Cl}^{-}\right]$were determined in a 1:5 solution (soil/water). The correlative numbers on the $\mathrm{X}$-axis refer to the months that had passed, with cultivation, since the beginning of the trials.

\subsection{Relationships between Biochemical Soil Quality Indicators}

The values of Pearson's correlation coefficient between biochemical soil quality indicators are shown in Table 6. Significant positive correlations $(p<0.01)$ were found for all soil quality indicators. There was a good correlation between TOC and each of the labile organic carbon fractions, and POC showed the highest value $(r=0.78)$; at the same time, POC showed the best correlation coefficient with LF $(r=0.81)$. WSOC was the labile organic carbon fraction that showed the lowest correlation coefficient with DH and GL ( $r=0.73$ and $r=0.68$, respectively). There was also a good correlation between the two soil enzymes and all the indicators related to organic carbon, especially between 
DH and POC $(r=0.83)$ and LF $(r=0.85)$, with DH having higher correlation coefficients than GL. EC showed a higher correlation coefficient with WSOC $(r=0.78)$ and LF $(r=0.77)$, the $\left[\mathrm{NO}_{3}{ }^{-}\right]$of the soil solution also showed a higher correlation coefficient with both labile organic carbon fractions $(r=0.74$ and $r=0.71$, respectively) and with $\mathrm{DH}(r=0.66)$, and the $\left[\mathrm{Cl}^{-}\right]$of the soil solution showed the best correlation coefficients with the same indicators, better than the $\left[\mathrm{NO}_{3}{ }^{-}\right]$(WSOC: $r=0.66 ; \mathrm{LF}: r=0.65$; DH: $r=0.64)$.

Table 6. Pearson's correlation coefficients ( $\mathrm{r}$ ) between the different soil quality indicators. TOC: total organic carbon ( $\mathrm{g} \mathrm{kg}^{-1}$ soil); POC: particulate organic carbon ( $\mathrm{g} \mathrm{kg}^{-1}$ soil); LF: light fraction $\left(\mathrm{g} \mathrm{kg}^{-1}\right.$ soil); WSOC: water-soluble organic carbon ( $\mathrm{g} \mathrm{kg}^{-1}$ soil); $\mathrm{DH}$ : dehydrogenase activity (mg TPF kg-1 soil day $\left.{ }^{-1}\right)$; GL: $\beta$-glucosidase activity ( $\mu \mathrm{mol} \mathrm{PNG} \mathrm{kg}{ }^{-1}$ soil $\left.\mathrm{h}^{-1}\right)$; EC: electrical conductivity $\left(\mathrm{dS} \mathrm{m}^{-1}\right)$; $\left[\mathrm{NO}_{3}{ }^{-}\right]$: concentration of nitrates of the soil solution; $\left[\mathrm{Cl}^{-}\right]$: concentration of chlorides of the soil solution. $\mathrm{EC},\left[\mathrm{NO}_{3}{ }^{-}\right]$and $\left[\mathrm{Cl}^{-}\right]$were determined in a 1:5 solution (soil/water). The $p$-value was less than or equal to $0.01(p<0.01)$ for all coefficients.

\begin{tabular}{cccccccccc}
\hline & TOC & POC & LF & WSOC & DH & GL & EC & {$\left[\mathrm{NO}_{3}^{-}\right]$} & {$\left[\mathrm{Cl}^{-}\right]$} \\
\hline TOC & 1 & & & & & & & & \\
POC & 0.78 & 1 & & & & & & & \\
LF & 0.76 & 0.81 & 1 & & & & & & \\
WSOC & 0.73 & 0.68 & 0.75 & 1 & & & & & \\
DH & 0.79 & 0.83 & 0.85 & 0.73 & 1 & & & & \\
GL & 0.77 & 0.70 & 0.76 & 0.68 & 0.76 & 1 & & & \\
EC & 0.76 & 0.61 & 0.77 & 0.78 & 0.71 & 0.70 & 1 & & \\
[NO $\left._{3}^{-}\right]$ & 0.64 & 0.62 & 0.71 & 0.74 & 0.66 & 0.61 & 0.81 & 1 & \\
{$\left[\mathbf{C l}^{-}\right]$} & 0.63 & 0.54 & 0.65 & 0.66 & 0.64 & 0.62 & 0.77 & 0.87 & 1 \\
\hline
\end{tabular}

\subsection{Measurements of Crop N Status}

Plants in CMP had significantly higher values of petiole sap $\left[\mathrm{NO}_{3}{ }^{-}\right]$in the three cropping seasons, except at 50 days after transplantation in the first two cropping seasons, than those in CRTMP (Figure 3). The mean values of petiole sap $\left[\mathrm{NO}_{3}{ }^{-}\right]$in both management packages, especially in $\mathrm{CMP}$, were above $1500 \mathrm{mg} \mathrm{L}^{-1}$, the maximum sufficiency value established by Peña-Fleitas [67] and Hochmuth [66].

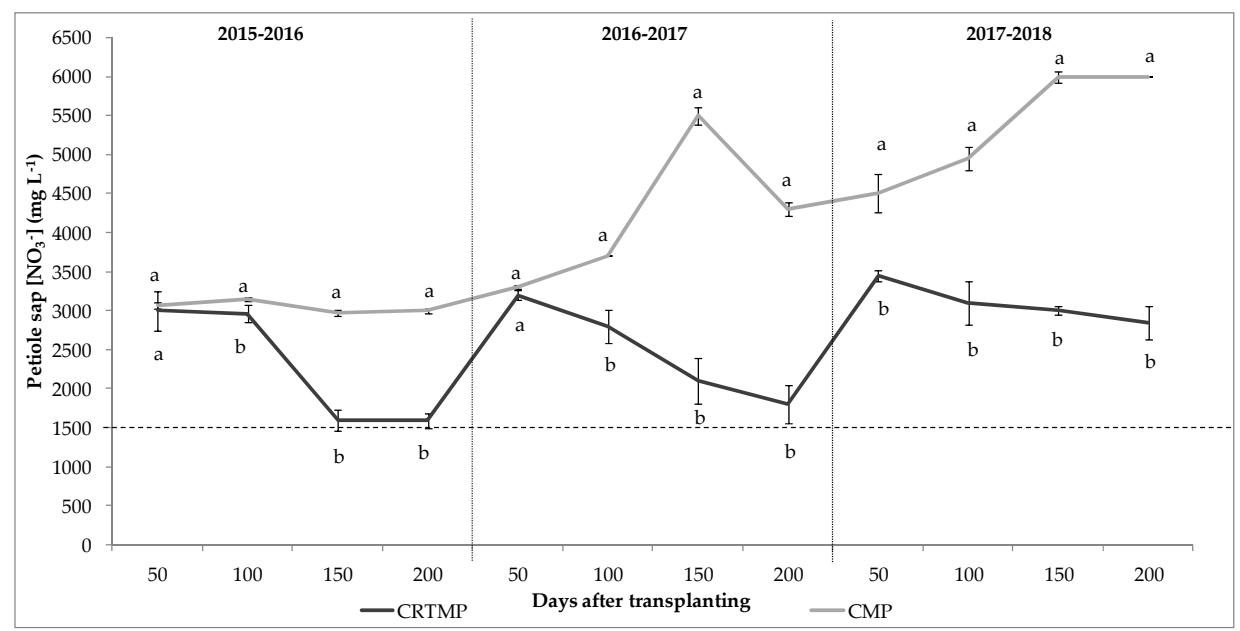

Figure 3. The values of petiole sap $\left[\mathrm{NO}_{3}{ }^{-}\right]$measured throughout the three cropping seasons for each of the two management packages. Values are means \pm SE. Different letters indicate significant differences $(p<0.05)$ between the management packages. The vertical dotted lines indicate the beginning of the cropping season. The horizontal dashed line indicates the sufficiency value of petiole sap $\left[\mathrm{NO}_{3}{ }^{-}\right]$in the greenhouse sweet pepper crop in Almeria $\left(1500 \mathrm{mg} \mathrm{L}^{-1}\right)$, established by Peña-Fleitas [67]. 


\subsection{Crop Yield}

Total production was significantly $(p<0.05)$ higher in the CMP management package in each of the three cropping seasons. The discard was also significantly $(p<0.05)$ higher in CMP, except for in the third cropping season (2017-2018). By contrast, there were no significant $(p<0.05)$ differences in category 1 and 2 production between the management packages, except in the third cropping season, in which both productions were significantly $(p<0.05)$ higher in CMP (Table 7$)$.

Table 7. The mean productions of category 1, category 2, total, and discard in each cropping season in both management packages (CMP and CRTMP) $(n=4)$. Different letters indicate significant differences $(p<0.05)$ between the production values in the same row. Standard deviations are in brackets. Production is expressed in $\mathrm{kg} \mathrm{m}^{-2}$ (fresh weight).

\begin{tabular}{cccc}
\hline \multirow{2}{*}{ Production $\left(\mathbf{k g ~ m}^{-2}\right)$} & Crop Season & \multicolumn{2}{c}{ Management Package } \\
\cline { 2 - 4 } & & CMP & CRTMP \\
\hline \multirow{2}{*}{ Category 1} & $2015-2016$ & $5.48(1.23) \mathrm{a}$ & $4.80(0.95) \mathrm{a}$ \\
& $2016-2017$ & $3.75(0.66) \mathrm{a}$ & $4.30(0.35) \mathrm{a}$ \\
& $2017-2018$ & $4.60(0.44) \mathrm{a}$ & $3.24(0.47) \mathrm{b}$ \\
\hline \multirow{2}{*}{ Category 2 } & $2015-2016$ & $3.18(1.16) \mathrm{a}$ & $2.05(0.35) \mathrm{a}$ \\
& $2016-2017$ & $4.33(0.67) \mathrm{a}$ & $3.22(0.45) \mathrm{a}$ \\
& $2017-2018$ & $3.43(0.38) \mathrm{a}$ & $1.91(0.43) \mathrm{b}$ \\
\hline \multirow{2}{*}{ Discard } & $2015-2016$ & $1.60(0.32) \mathrm{a}$ & $0.72(0.29) \mathrm{b}$ \\
& $2016-2017$ & $1.97(0.53) \mathrm{a}$ & $0.85(0.29) \mathrm{b}$ \\
Total & $2017-2018$ & $0.64(0.28) \mathrm{a}$ & $0.61(0.16) \mathrm{a}$ \\
\hline & $2015-2016$ & $10.26(0.60) \mathrm{a}$ & $7.57(0.62) \mathrm{b}$ \\
& $2016-2017$ & $10.05(0.93) \mathrm{a}$ & $8.34(0.23) \mathrm{b}$ \\
& $2017-2018$ & $8.66(0.40) \mathrm{a}$ & $5.76(0.56) \mathrm{b}$ \\
\hline
\end{tabular}

The seasonal evolution of cumulative category 1, category 2 and total fresh fruit production indicated that significant differences between the packages in the third cropping season occurred almost entirely in the final part of the cropping season, particularly in the last two harvests, when fruit production in the CMP package increased sharply (Figure 4).

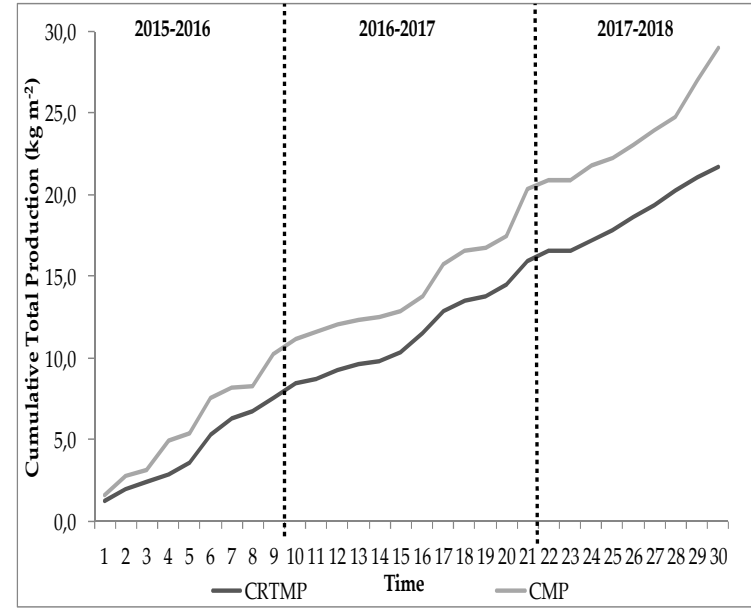

(a)

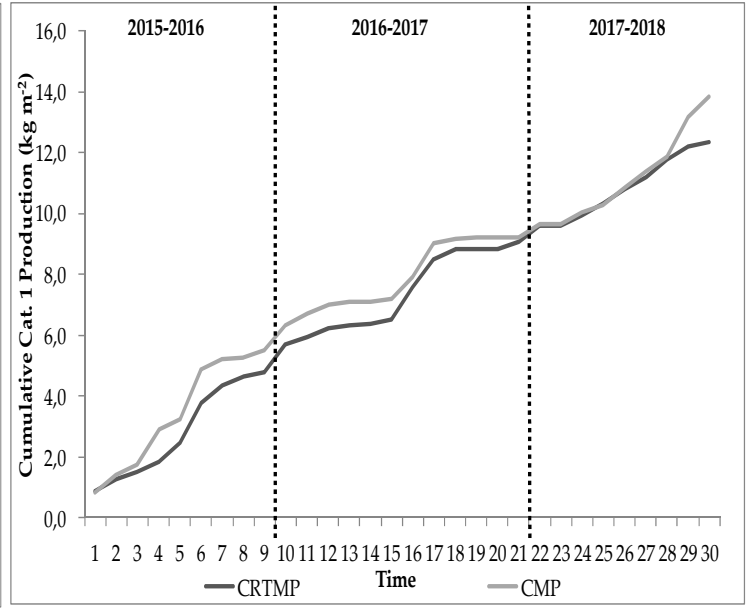

(b)

Figure 4. Cont. 


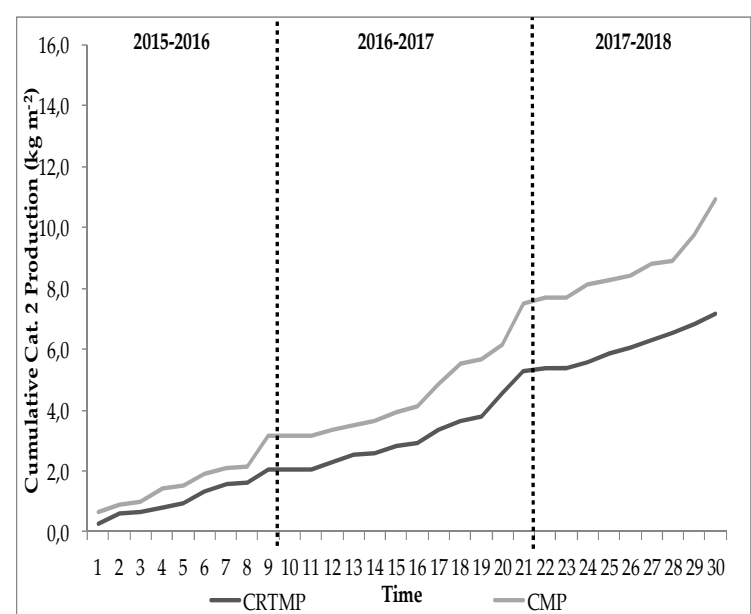

(c)

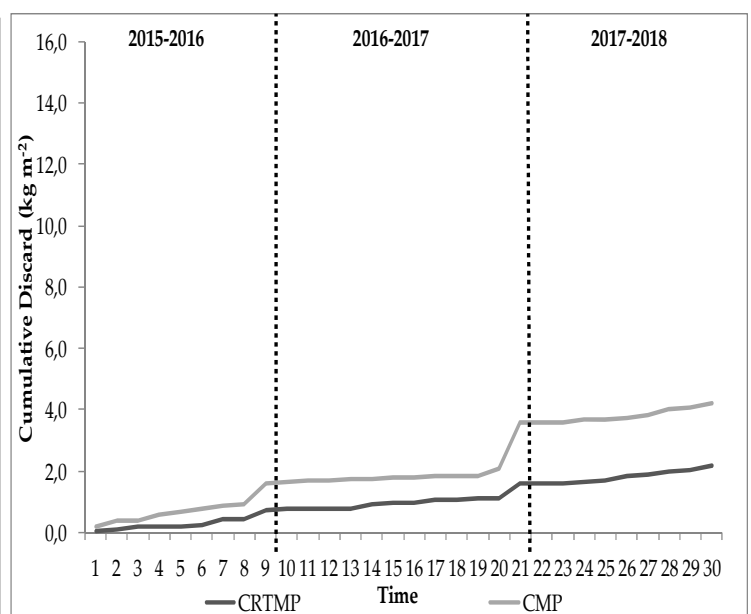

(d)

Figure 4. The seasonal evolution of cumulative (a) category 1, (b) category 2 and (c) total fresh fruit production, and (d) discard, in the two management packages (CRTMP and CMP) during the three study cropping seasons (2015-2016, 2016-2017 and 2017-2018).

The percentage of category 1 production in relation to total production was higher in CRTMP in the three cropping seasons, and the percentage of category 1 and 2 (marketable) production was higher in the first two cropping seasons in CRTMP, while in the third cropping season, such relative increases did not occur because of the sharp increase in the final part of the cropping season in CMP (Figure 5).

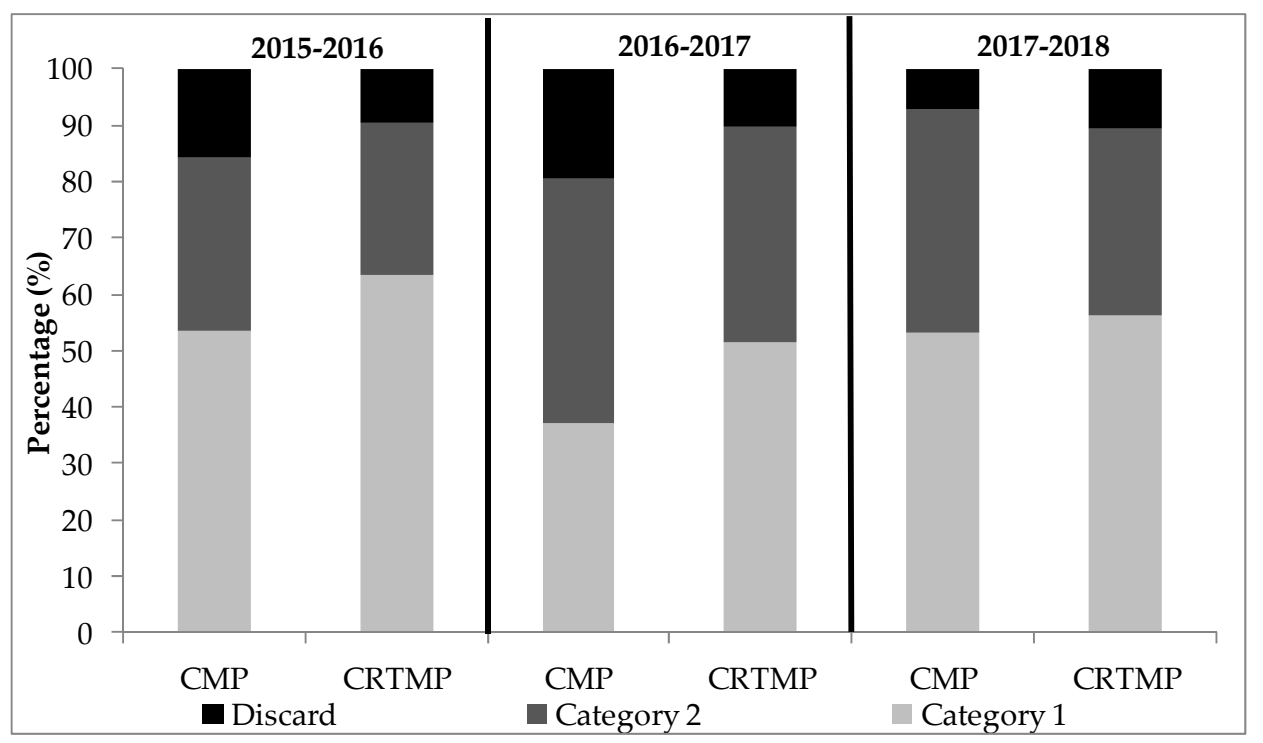

Figure 5. Percentages (\%) of category 1 and 2 production and discard, in relation to total production, in the two management packages (CRTMP and CMP) during the three study cropping seasons (2015-2016, 2016-2017 and 2017-2018).

\section{Discussion}

The application of organic amendments and their incorporation into the soil through tillage increases TOC levels from the first year of cultivation, achieving the desired values in greenhouse soils in the province of Almeria ( $>15 \mathrm{~g} \mathrm{~kg}^{-1}$ soil) [68], as is to be expected and as has been noted by numerous authors $[69,70]$. However, the continuous incorporation of amendments in the different seasons does not contribute to a remarkable differential increase in this indicator, which remains at the same average levels throughout the different seasons. This behavior qualifies it as suitable only for comparisons between different greenhouse management practices, but not for evaluating the 
variation in soil quality due to the repeated application of the same management over time. Similar results have been obtained by [71,72]. Tillage distributed carbon labile fractions and improved the conditions for enzyme activity in CRTMP, allowing higher mean values in all soil quality indicators in the $0-15 \mathrm{~cm}$ depth range, even from the first cropping season. The higher variability shown in mean values of the biochemical soil quality indicators in CRTMP may be due to changes in the soil's physicochemical properties, soil biota activity, soil composition, and the interaction between them $[73,74]$. The considerable increases in CRTMP in the labile fractions (POC and LF) serve as an important factor in providing energy to heterotrophic microbial organisms $[75,76]$ and can function as a nucleation site for microbial activity [77], which justifies their significant correlations with soil quality indicators related to enzymatic activity (DH and GL). In this sense, the mean values of DH progressively increase as do the mean values of mineralizable substrates (POC and LF), especially in the second and third cropping seasons. POC and LF, although not equivalent, are closely related, as a part of LF can be part of POC [78], so they are often mistakenly confused [79], which justifies the high correlation coefficient between them. Our results suggest POC as good indicator of soil quality after a short-term change in greenhouse management due to its high sensitivity, and the high and significant correlations with the TOC, enzymatic activities and $\left[\mathrm{NO}_{3}{ }^{-}\right]$of the soil solution. The labile fraction increases after organic management are consistent with other studies [26,80], as well as the supply of soil $\mathrm{N}$ for crops [81].

Despite the considerable increase in WSOC in CRTMP compared to the initial state, it also increased considerably in CMP, with no significant differences between the management packages in some months, suggesting that it may be affected by factors other than those involved in the management practices used [82]. Some studies support the relationship between WSOC and microbial activity, so that the microbial community can easily use energy sources such as metabolizable organic compounds, extracted as WSOC from the decomposition of the soil organic matter [83,84]; instead, our results show the lowest correlation of WSOC with microbial activity indicators (DH and GL).

In general, an improvement in soil enzyme activity results from increased microbial synthesis due to improved environmental conditions induced by changes in the soil's physicochemical properties $[85,86]$ and could be indicative of the mineralization of organic matter by soil microorganisms [87]. The intracellular activity of the DH enzyme justifies the highest correlation with indicators related to organic carbon $[45,88]$, while GL is present in the processes of cellulose degradation present in plant remains [48,89], suggesting that the DH enzyme is more sensitive to short-term management changes [90]. Authors such as Okur et al. [16] and Zhang et al. [17] have reported that the contribution of organic matter to the soil causes an increase in enzymatic activity, while others [91,92] have reported a decrease in such activity when soils are intensively fertilized with nitrogen, as it was in CMP. These pieces of evidence allow the justification of the differences found between the different management packages tested in this trial. The increases in and correlations between enzyme activity and organic carbon indicators suggest a balanced improvement of soil biological activity, as observed by Yevdokimov et al. [93] and Saikia et al. [94]. These increases are detected from the first cropping season and are maintained throughout the three cropping seasons of study, even in TOC, despite this being an indicator less susceptible, in the short or medium term, to management changes [26,27].

The results of this study showed that the application of CRTMP, in addition to improving soil quality indicators, increased the concentration of nitrates in the soil solution. This could be due, on the one hand, to the direct contribution of soluble nitrogen salts present in the organic amendments but, on the other hand, to the mineralization of the organic matter. The proof for this is the significant correlation between the $\left[\mathrm{NO}_{3}{ }^{-}\right]$of soil solution and indicators related to labile organic carbon fractions and enzymatic activity. However, CRTMP, due to the high $\mathrm{Cl}^{-}$content of the selected organic amendments and the comparatively small amount of drainage, also significantly increased the chloride concentration of the soil solution and the soil electrical conductivity. The $\left[\mathrm{Cl}^{-}\right]$of the soil solution and soil salinization could have effected the significantly lower total production in CRTMP compared to in CMP; in the third cropping season, moreover, significant differences were detected in the petiole 
sap $\left[\mathrm{NO}_{3}{ }^{-}\right.$] - a sensitive indicator of crop $\mathrm{N}$ status in the sweet pepper [95]—in the initial stages between the management packages, contrary to in the two previous cropping seasons, and this could have influenced the significant decrease in marketable and total production. The higher crop yield in CMP can be explained because this practice provides a readily available source of $\mathrm{N}$, which is one of the main factors controlling crop yield [96], in the dripper by fertigation. Padilla et al. [3] also observed differences in crop yields in greenhouses in Almería (Spain) with the incorporation of organic amendments, mainly due to the increase in production at the end of the cropping seasons in CMP. This higher total production in CMP at the end of the cropping season is probably related to the higher differences in petiole sap $\left[\mathrm{NO}_{3}{ }^{-}\right]$detected between the management packages after the winter season. The lower values of $\left[\mathrm{NO}_{3}{ }^{-}\right]$in the petiole sap in CRTMP may be related to the competition between chlorides and nitrates for uptake from the soil [97,98], thus decreasing nitrate uptake compared to in CMP. Other authors such as Hernández et al. [87] achieved crop yields similar to or even higher than with conventional management in lettuce crops. Although the total production is significantly lower in CRTMP, this form of management is able to increase the fruit quality, which could economically compensate for the difference in total production due to its high value-added nature [26,99], as well as benefit the environment. Other authors observed better results, in terms of quality parameters, in outdoor melon crops with organic management practices compared to with conventional management [100].

Despite the clear improvements that the CRTMP management package induces in the measured biochemical parameters, the high risk of salinization requires a reconsideration of the organic materials used together with the crop residues, as well as the establishment of irrigation schedules that help to minimize this risk [101].

\section{Conclusions}

Management practices including the tillage and the contribution of crop residues and organic fertilizer in greenhouse soil increase the soil's organic carbon and its labile fractions, thus increasing its enzymatic activity. These improvements in the biochemical indicators of soil quality in the short term occur during three consecutive cropping seasons of sweet pepper in greenhouses and in the first $15 \mathrm{~cm}$ of the soil, with considerable improvements from the first cropping season. POC and DH demonstrate, in this cultivation system, their double utility as indicators of soil quality. On the one hand, they will make it possible to establish whether there are differences between different management practices at any given time. On the other hand, they will make it possible to evaluate the effects produced by a change in management over time. In addition to the biochemical indicators, the concentration of nitrates in the soil solution also increases. However, the organic matter used increases the risk of soil salinization in greenhouses, by increasing the concentration of chlorides in the soil solution, and decreases the concentration of nitrates in the petiole sap, which is related to a decrease in total production but an increase in production quality. In this type of management, the optimal management of water and fertilizers is important and advisable to prevent the problem of soil salinization and also to avoid the loss of nutrients provided by organic amendments, especially at the beginning of the cropping season.

In future lines of research, it would be desirable to advance the knowledge about the behavior in greenhouses of different quality indicators—physical, chemical and biological—that allow a composite index of soil quality (SQI) related to the production of these systems to be obtained.

Author Contributions: Conceptualization, J.S. and F.d.M.; methodology, J.S. and F.d.M.; formal analysis, J.S. and F.d.M.; resources, D.M.; writing—original draft preparation, J.S.; writing—review and editing, J.S., D.M. and F.d.M.; funding acquisition, D.M. and F.d.M. All authors have read and agreed to the published version of the manuscript.

Funding: The field experimentation has been financed by the Cajamar Foundation.

Acknowledgments: The authors wish to express their gratitude for the supervision of the crops during the cropping seasons carried out by the technical commission of the Experimental Station of the Cajamar Foundation. 
Conflicts of Interest: The authors declare no conflict of interest. The funders had no role in the design of the study; in the collection, analyses, or interpretation of data; in the writing of the manuscript, or in the decision to publish the results.

\section{References}

1. Cajamar Caja Rural. Análisis de la Campaña Hortofrutícola de Almería: Campaña 2017/2018; Cajamar Caja Rural: Almería, Spain, 2018.

2. Bonachela, S.; Granados, M.R.; López, J.C.; Hernández, J.; Magán, J.J.; Baeza, E.J.; Baille, A. How plastic mulches affect the thermal and radiative microclimate in an unheated low-cost greenhouse. Agric. Meteorol. 2012, 152, 65-72. [CrossRef]

3. Padilla, F.M.; Peña-Fleitas, M.T.; Fernández, M.D.; del Moral, F.; Thompson, R.B.; Gallardo, M. Responses of soil properties, crop yield and root growth to improved irrigation and $\mathrm{N}$ fertilization, soil tillage and compost addition in a pepper crop. Sci. Hortic. (Amst.) 2017, 225, 422-430. [CrossRef]

4. Thompson, R.B.; Gallardo, M.; Valdez, L.C.; Fernández, M.D. Using plant water status to define threshold values for irrigation management of vegetable crops using soil moisture sensors. Agric. Water Manag. 2007, 88, 147-158. [CrossRef]

5. Nikolaou, G.; Neocleous, D.; Katsoulas, N.; Kittas, C. Irrigation of greenhouse crops. Horticulturae 2019 , 5, 7. [CrossRef]

6. Wu, T.; Milner, H.; Díaz-Pérez, J.C.; Ji, P. Effects of soil management practices on soil microbial communities and development of southern blight in vegetable production. Appl. Soil Ecol. 2015, 91, 58-67. [CrossRef]

7. Rivera-Becerril, F.; van Tuinen, D.; Chatagnier, O.; Rouard, N.; Béguet, J.; Kuszala, C.; Soulas, G.; Gianinazzi-Pearson, V.; Martin-Laurent, F. Impact of a pesticide cocktail (fenhexamid, folpel, deltamethrin) on the abundance of Glomeromycota in two agricultural soils. Sci. Total Environ. 2017, 577, 84-93. [CrossRef]

8. Norris, C.E.; Congreves, K.A. Alternative management practices improve soil health indices in intensive vegetable cropping systems: A review. Front. Environ. Sci. 2018, 6, 50. [CrossRef]

9. Xu, L.; Wang, M.; Tian, Y.; Shi, X.; Shi, Y.; Yu, Q.; Xu, S.; Li, X.; Xie, X. Changes in soil macropores: Superposition of the roles of organic nutrient amendments and the greenhouse pattern in vegetable plantations. Soil Use Manag. 2019, 35, 412-420. [CrossRef]

10. Molina-Sánchez, L.; Sánchez-Martos, F.; Daniele, L.; Vallejos, A.; Pulido-Bosch, A. Interaction of aquifer-wetland in a zone of intensive agriculture: The case of Campo de Dalías (Almería, SE Spain). Environ. Earth Sci. 2015, 73, 2869-2880. [CrossRef]

11. Foster, S.; Pulido-Bosch, A.; Vallejos, Á.; Molina, L.; Llop, A.; MacDonald, A.M. Impact of irrigated agriculture on groundwater-recharge salinity: A major sustainability concern in semi-arid regions. Hydrogeol. J. 2018, 26, 2781-2791. [CrossRef]

12. Egea, F.J.; Torrente, R.G.; Aguilar, A. An efficient agro-industrial complex in Almería (Spain): Towards an integrated and sustainable bioeconomy model. N. Biotechnol. 2018, 40, 103-112. [CrossRef]

13. Oldfield, E.E.; Bradford, M.A.; Wood, S.A. Global meta-analysis of the relationship between soil organic matter and crop yields. Soil 2019, 5, 15-32. [CrossRef]

14. Das, A.; Lal, R.; Patel, D.P.; Idapuganti, R.G.; Layek, J.; Ngachan, S.V.; Ghosh, P.K.; Bordoloi, J.; Kumar, M. Effects of tillage and biomass on soil quality and productivity of lowland rice cultivation by small scale farmers in North Eastern India. Soil Tillage Res. 2014, 143, 50-58. [CrossRef]

15. Sánchez-Monedero, M.A.; Cayuela, M.L.; Sánchez-García, M.; Vandecasteele, B.; D’Hose, T.; López, G.; Martínez-Gaitán, C.; Kuikman, P.J.; Sinicco, T.; Mondini, C. Agronomic evaluation of biochar, compost and biochar-blended compost across different cropping systems: Perspective from the European project FERTIPLUS. Agronomy 2019, 9, 225.

16. Okur, N.; Göçmez, S.; Tüzel, Y. Effect of organic manure application and solarization on soil microbial biomass and enzyme activities under greenhouse conditions. Biol. Agric. Hortic. 2006, 23, 305-320. [CrossRef]

17. Zhang, L.; Chen, W.; Burger, M.; Yang, L.; Gong, P.; Wu, Z. Changes in soil carbon and enzyme activity as a result of different long-term fertilization regimes in a greenhouse field. PLoS ONE 2015, 10, 1-13. [CrossRef]

18. Musyoka, M.; Adamtey, N.; Muriuki, A.W.; Bautze, D.; Karanja, E.N.; Mucheru-Muna, M.; Fiaboe, K.K.M.; Cadisch, G. Nitrogen leaching losses and balances in conventional and organic farming systems in Kenya. Nutr. Cycl. Agroecosystems 2019, 114, 237-260. [CrossRef] 
19. Del Moral, F.; González, V.; Simón, M.; García, I.; Sánchez, J.A.; de Haro, S. Soil properties after 10 years of organic versus conventional management in two greenhouses in Almeria (SE Spain). Arch. Agron. Soil Sci. 2012, 58, S226-S231. [CrossRef]

20. Bhardwaj, A.K.; Jasrotia, P.; Hamilton, S.K.; Robertson, G.P. Ecological management of intensively cropped agro-ecosystems improves soil quality with sustained productivity. Agric. Ecosyst. Environ. 2011, 140, 419-429. [CrossRef]

21. Reinhart, K.O.; Nichols, K.A.; Petersen, M.; Vermeire, L.T. Soil aggregate stability was an uncertain predictor of ecosystem functioning in a temperate and semiarid grassland. Ecosphere 2015, 6, 1-16. [CrossRef]

22. Obade, V.; Lal, R. Towards a standard technique for soil quality assessment. Geoderma 2016, 265, 96-102. [CrossRef]

23. Mondini, C.; Bigot, G.; Sinicco, T.; Mosetti, D. Biochemical indicators of soil fertility in vineyards with different conservative management systems. Bio. Web Conf. 2019, 13, 04009. [CrossRef]

24. Komatsuzaki, M.; Ohta, H. Soil management practices for sustainable agro-ecosystems. Sustain. Sci. 2007, 2, 103-120. [CrossRef]

25. Blanco-Canqui, H.; Shapiro, C.A.; Wortmann, C.S.; Drijber, R.A.; Mamo, M.; Shaver, T.M.; Ferguson, R.B. Soil organic carbon: The value to soil properties. J. Soil Water Conserv. 2013, 68, A129-A134. [CrossRef]

26. Bongiorno, G.; Bünemann, E.K.; Oguejiofor, C.U.; Meier, J.; Gort, G.; Comans, R.; Mäder, P.; Brussaard, L.; de Goede, R. Sensitivity of labile carbon fractions to tillage and organic matter management and their potential as comprehensive soil quality indicators across pedoclimatic conditions in Europe. Ecol. Indic. 2019, 99, 38-50. [CrossRef]

27. Zhu, L.; Hu, N.; Zhang, Z.; Xu, J.; Tao, B.; Meng, Y. Short-term responses of soil organic carbon and carbon pool management index to different annual straw return rates in a rice-wheat cropping system. Catena 2015, 135, 283-289. [CrossRef]

28. Kumar, S.; Garg, A.K.; Aulakh, M.S. Effect of Conservation Agriculture Practices on Physical, Chemical and Biological Attributes of Soil Health under Soybean-Rapeseed Rotation. Agric. Res. 2016, 5, 145-161. [CrossRef]

29. Blanco-Moure, N.; Gracia, R.; Bielsa, A.; López, M. Long-term no-tillage effects on particulate and mineral-associated soil organic matter under rainfed Mediterranean condition. Soil Use Manag. 2013, 29, 250-259. [CrossRef]

30. Yang, X.; Ren, W.; Sun, B.; Zhang, S. Effects of contrasting soil management regimes on total and labile soil organic carbon fractions in a loess soil in China. Geoderma 2012, 177-178, 49-56. [CrossRef]

31. Galantini, J.; Duval, M.; Iglesias, J.; Kruger, H. Continuous Wheat in Semiarid Regions: Long-term Effects on Stock and Quality of Soil Organic Carbon. Soil Sci. 2014, 179, 284-292. [CrossRef]

32. Wang, Q.; Wang, Y.; Wang, Q.; Liu, J. Impacts of 9 years of a new conservational agricultural management on soil organic carbon fractions. Soil Tillage Res. 2014, 143, 1-6. [CrossRef]

33. Zhijun, H.; Selvalakshmi, S.; Vasu, D.; Liu, Q.; Cheng, H.; Guo, F.; Ma, X. Identification of indicators for evaluating and monitoring the effects of Chinese fir monoculture plantations on soil quality. Ecol. Indic. 2018, 93, 547-554. [CrossRef]

34. Jokela, W.E.; Grabber, J.H.; Karlen, D.L.; Balser, T.C.; Palmquist, D.E. Cover crop and liquid manure effects on soil quality indicators in a corn silage system. Agron. J. 2009, 101, 727-737. [CrossRef]

35. Gosling, P.; Parsons, N.; Bending, G.D. What are the primary factors controlling the light fraction and particulate soil organic matter content of agricultural soils? Biol. Fertil. Soils 2013, 49, 1001-1014. [CrossRef]

36. Monaci, E.; Polverigiani, S.; Neri, D.; Bianchelli, M.; Santilocchi, R.; Toderi, M.; D’Ottavio, P.; Vischetti, C. Effect of contrasting crop rotation systems on soil chemical and biochemical properties and plant root growth in organic farming: First results. Ital. J. Agron. 2017, 12, 364-374. [CrossRef]

37. Bowles, T.M.; Acosta-Martínez, V.; Calderón, F.; Jackson, L.E. Soil enzyme activities, microbial communities, and carbon and nitrogen availability in organic agroecosystems across an intensively-managed agricultural landscape. Soil Biol. Biochem. 2014, 68, 252-262. [CrossRef]

38. Dong, W.Y.; Zhang, X.Y.; Dai, X.Q.; Fu, X.L.; Yang, F.T.; Liu, X.Y.; Sun, X.M.; Wen, X.F.; Schaeffer, S. Changes in soil microbial community composition in response to fertilization of paddy soils in subtropical China. Appl. Soil Ecol. 2014, 84, 140-147. [CrossRef] 
39. Luo, P.; Han, X.; Wang, Y.; Han, M.; Shi, H.; Liu, N.; Bai, H. Influence of long-term fertilization on soil microbial biomass, dehydrogenase activity, and bacterial and fungal community structure in a brown soil of northeast China. Ann. Microbiol. 2015, 65, 533-542. [CrossRef]

40. Torres, I.F.; Bastida, F.; Hernández, T.; Albaladejo, J.; García, C. Enzyme activity, microbial biomass and community structure in a long-term restored soil under semi-arid conditions. Soil Res. 2015, 53, 553-560. [CrossRef]

41. Melo, W.; Delarica, D.; Guedes, A.; Lavezzo, L.; Donha, R.; de Araújo, A.; de Melo, G.; Macedo, F. Ten years of application of sewage sludge on tropical soil. A balance sheet on agricultural crops and environmental quality. Sci. Total Environ. 2018, 643, 1493-1501. [CrossRef]

42. Jat, H.S.; Datta, A.; Choudhary, M.; Sharma, P.C.; Yadav, A.K.; Choudhary, V.; Gathala, M.K.; Jat, M.L.; McDonald, A. Climate Smart Agriculture practices improve soil organic carbon pools, biological properties and crop productivity in cereal-based systems of North-West India. Catena 2019, 181, 104059. [CrossRef]

43. Nyiraneza, J.; Vernon, R.; Yvonne, U.; Fraser, T.D.; Erin, S.; Fillmore, S.A.E.; Mills, A. Long-Term Manure Application Effects on Nutrients and Selected Enzymes Involved in Their Cycling. Soil Sci. Soc. Am. J. 2018, 82, 1404-1414. [CrossRef]

44. Brennan, E.B.; Acosta-Martinez, V. Cover Crops and Compost Influence Soil Enzymes during Six Years of Tillage-Intensive, Organic Vegetable Production. Soil Sci. Soc. Am. J. 2019, 83, 624-637. [CrossRef]

45. Järvan, M.; Edesi, L.; Adamson, A.; Võsa, T. Soil microbial communities and dehydrogenase activity depending on farming systems. Plant Soil Environ. 2014, 60, 459-463. [CrossRef]

46. Alkorta, I.; Aizpurua, A.; Riga, P.; Albizu, I.; Amézaga, I.; Garbisu, C. Soil enzyme activities as biological indicators of soil health. Rev. Environ. Health 2003, 18, 65-73. [CrossRef] [PubMed]

47. Dick, R.P.; Breakwell, D.P.; Turco, R.F. Soil Enzyme Activities and Biodiversity Measurements as Integrative Microbiological Indicators. Methods Assess. Soil Qual. 1997, 247-271.

48. Martinez, C.E.; Tabatabai, M.A. Decomposition of Biotechnology By-Products in Soils. J. Environ. Qual. 1997, 26, 625-632. [CrossRef]

49. Merino, C.; Godoy, R.; Matus, F. Soil enzymes and biological activity at different levels of organic matter stability. J. Soil Sci. Plant Nutr. 2016, 16, 14-30.

50. Knight, T.R.; Dick, R.P. Differentiating microbial and stabilized $\beta$-glucosidase activity relative to soil quality. Soil Biol. Biochem. 2004, 36, 2089-2096. [CrossRef]

51. Gura, I.; Mnkeni, P.N.S. Crop rotation and residue management effects under no till on the soil quality of a Haplic Cambisol in Alice, Eastern Cape, South Africa. Geoderma 2019, 337, 927-934. [CrossRef]

52. Thompson, R.B.; Gallardo, M.; Joya, M.; Martínez Gaitán, C.; Granados, M.R.; Segovia, C. Evaluation of rapid analysis systems for on-farm nitrate analysis in vegetable cropping. Span. J. Agric. Res. 2009, 7, 200-211. [CrossRef]

53. Isayenkov, S.V.; Maathuis, F.J.M. Plant salinity stress: Many unanswered questions remain. Front. Plant Sci. 2019, 10, 80. [CrossRef] [PubMed]

54. Paul, D.; Lade, H. Plant-growth-promoting rhizobacteria to improve crop growth in saline soils: A review. Agron. Sustain. Dev. 2014, 34, 737-752. [CrossRef]

55. Mingorance, M.D.; Barahona, E.; Fernández-Gálvez, J. Guidelines for improving organic carbon recovery by the wet oxidation method. Chemosphere 2007, 68, 409-413. [CrossRef] [PubMed]

56. Cambardella, C.A.; Elliot, E.T. Particulate soil organic-matter changes across a grassland cultivation sequence. Soil Sci. Soc. Am. J. 1992, 56, 777-783. [CrossRef]

57. Gregorich, E.G.; Carter, M.R.; Angers, D.A.; Monreal, C.M.; Ellert, B.H. Towards a minimum data set to assess soil organic matter quality in agricultural soils. Can. J. Soil Sci. 1994, 74, 367-385. [CrossRef]

58. Scaglia, B.; Adani, F. Biodegradability of soil water soluble organic carbon extracted from seven different soils. J. Environ. Sci. 2009, 21, 641-646. [CrossRef]

59. Neogi, S.; Bhattacharyya, P.; Roy, K.S.; Panda, B.B.; Nayak, A.K.; Rao, K.S.; Manna, M.C. Soil respiration, labile carbon pools, and enzyme activities as affected by tillage practices in a tropical rice-maize-cowpea cropping system. Environ. Monit. Assess. 2014, 186, 4223-4236. [CrossRef]

60. Eivazi, F.; Tabatabai, M.A. Glucosidases and galactosidases in soils. Soil Biol. Biochem. 1988, 20, 601-606. [CrossRef]

61. Soil Quality—Determination of the Specific Electrical Conductivity; UNE standards: Madrid, Spain, 31 January 2001; UNE 77308:2001. 
62. Soil Improvers and Growing Media-Determination of Electrical Conductivity; UNE standards: Madrid, Spain, 16 May 2012; UNE-EN 13038:2012.

63. Marañés, A.; Sánchez, J.A.; de Haro, S.; Sánchez, S.; del Moral, F. Análisis de Suelos: Metodología e Interpretación; Universidad de Almería: Almería, Spain, 1998.

64. Soil Quality—Determination of pH; UNE standards: Madrid, Spain, 21 March 2012; UNE-ISO 10390:2012.

65. Soil Improvers and Growing Media—Determination of $p H$; UNE standards: Madrid, Spain, 4 April 2012; UNE-EN 13037:2012.

66. Hochmuth, G. Plant Petiole Sap-Testing for Vegetable Crops. Available online: https://edis.ifas.ufl.edu/cv004 (accessed on 9 March 2020).

67. Peña-Fleitas, M.T. Medida del Estado Nutritivo del Cultivo por Análisis de Savia. Available online: https://www.cajamar.es/pdf/bd/agroalimentario/innovacion/formacion/actividades-de-transferencia/ 02a-medicion-del-estado-nutritivo-del-cultivo-por-analsis-de-savia-tere-pena-1465900678.pdf (accessed on 9 March 2020).

68. Fernández, M.; Aguilar, M.I.; Carrique, J.R.; Tortosa, J.; Garcia, C.; López, M.; Péres, J.M. Suelo y Medio Ambiente en Invernaderos, 5th ed.; Junta de Andalucía, Consejería de Agricultura, Pesca y Desarrollo Rural, Ed.; Secretaría General Técnica: Sevilla, Spain, 2014.

69. Lehtinen, T.; Schlatter, N.; Baumgarten, A.; Bechini, L.; Krüger, J.; Grignani, C.; Zavattaro, L.; Costamagna, C.; Spiegel, H. Effect of crop residue incorporation on soil organic carbon and greenhouse gas emissions in European agricultural soils. Soil Use Manag. 2014, 30, 524-538. [CrossRef]

70. Duval, M.E.; Martinez, J.M.; Galantini, J.A. Assessing soil quality indices based on soil organic carbon fractions in different long-term wheat systems under semiarid conditions. Soil Use Manag. 2020, 36, 71-82. [CrossRef]

71. Xu, M.; Lou, Y.; Sun, X.; Wang, W.; Baniyamuddin, M.; Zhao, K. Soil organic carbon active fractions as early indicators for total carbon change under straw incorporation. Biol. Fertil. Soils 2011, 47, 745-752. [CrossRef]

72. Leifeld, J.; Kögel-Knabner, I. Soil organic matter fractions as early indicators for carbon stock changes under different land-use? Geoderma 2005, 124, 143-155. [CrossRef]

73. Holík, L.; Hlisnikovský, L.; Honzík, R.; Trögl, J.; Burdová, H.; Popelka, J. Soil Microbial Communities and Enzyme Activities after Long-Term Application of Inorganic and Organic Fertilizers at Different Depths of the Soil Profile. Sustainability 2019, 11, 3251. [CrossRef]

74. Bardgett, R.D.; Lovell, R.D.; Hobbs, P.J.; Jarvis, S.C. Seasonal changes in soil microbial communities along a fertility gradient of temperate grasslands. Soil Biol. Biochem. 1999, 31, 1021-1030. [CrossRef]

75. Culman, S.W.; Snapp, S.S.; Green, J.M.; Gentry, L.E. Short- and long-term labile soil carbon and nitrogen dynamics reflect management and predict corn agronomic performance. Agron. J. 2013, 105, 493-502. [CrossRef]

76. Khatoon, H.; Solanki, P.; Narayan, M.; Tewari, L.; Rai, J.; Hina Khatoon, C. Role of microbes in organic carbon decomposition and maintenance of soil ecosystem. Int. J. Chem. Stud. 2017, 5, 1648-1656.

77. Denef, K.; Six, J.; Bossuyt, H.; Frey, S.D.; Elliott, E.T.; Merckx, R.; Paustian, K. Influence of dry-wet cycles on the interrelationship between aggregate, particulate organic matter, and microbial community dynamics. Soil Biol. Biochem.. 2001, 33, 1599-1611. [CrossRef]

78. Curtin, D.; Beare, M.H.; Qiu, W.; Sharp, J. Does Particulate Organic Matter Fraction Meet the Criteria for a Model Soil Organic Matter Pool? Pedosphere 2019, 29, 195-203. [CrossRef]

79. Semenov, V.M.; Lebedeva, T.N.; Pautova, N.B. Particulate Organic Matter in Noncultivated and Arable Soils. Eurasian Soil Sci. 2019, 52, 396-404. [CrossRef]

80. Li, J.; Wu, X.; Gebremikael, M.T.; Wu, H.; Cai, D.; Wang, B.; Li, B.; Zhang, J.; Li, Y.; Xi, J. Response of soil organic carbon fractions, microbial community composition and carbon mineralization to high-input fertilizer practices under an intensive agricultural system. PLoS ONE 2018, 13, e0195144. [CrossRef] [PubMed]

81. Haynes, R. Labile organic matter fractions as central components of the quality of agricultural soils: An overview. Adv. Agron. 2005, 85, 221-268.

82. Chantigny, M.H. Dissolved and water-extractable organic matter in soils: A review on the influence of land use and management practices. Geoderma 2003, 113, 357-380. [CrossRef]

83. Gonet, S.S.; Debska, B. Dissolved organic carbon and dissolved nitrogen in soil under different fertilization treatments. Plant Soil Environ. 2006, 52, 55-63. [CrossRef] 
84. Panettieri, M.; Berns, A.E.; Knicker, H.; Murillo, J.M.; Madejón, E. Evaluation of seasonal variability of soil biogeochemical properties in aggregate-size fractioned soil under different tillages. Soil Tillage Res. 2015, 151, 39-49. [CrossRef]

85. Aon, M.A.; Colaneri, A.C., II. Temporal and spatial evolution of enzymatic activities and physico-chemical properties in an agricultural soil. Appl. Soil Ecol. 2001, 18, 255-270. [CrossRef]

86. Tejada, M.; Hernandez, M.T.; Garcia, C. Soil restoration using composted plant residues: Effects on soil properties. Soil Tillage Res. 2009, 102, 109-117. [CrossRef]

87. Hernández, T.; Chocano, C.; Moreno, J.L.; García, C. Use of compost as an alternative to conventional inorganic fertilizers in intensive lettuce (Lactuca sativa L.) crops-Effects on soil and plant. Soil Tillage Res. 2016, 160, 14-22.

88. Taylor, J.P.; Wilson, B.; Mills, M.S.; Burns, R.G. Comparison of microbial numbers and enzymatic activities in surface soils and subsoils using various techniques. Soil Biol. Biochem. 2002, 34, 387-401. [CrossRef]

89. Gil-Sotres, F.; Trasar-Cepeda, C.; Leirós, M.C.; Seoane, S. Different approaches to evaluating soil quality using biochemical properties. Soil Biol. Biochem. 2005, 37, 877-887. [CrossRef]

90. Lipiec, J.; Frac, M.; Brzezinska, M.; Turski, M.; Oszust, K. Linking microbial enzymatic activities and functional diversity of soil around earthworm burrows and casts. Front. Microbiol. 2016, 7, 1361. [CrossRef] [PubMed]

91. Piotrowska-Długosz, A.; Wilczewski, E. Assessment of soil nitrogen and related enzymes as influenced by the incorporation time of field pea cultivated as a catch crop in Alfisol. Environ. Monit. Assess. 2014, 186, 8425-8441. [CrossRef] [PubMed]

92. Singh, B. Are Nitrogen Fertilizers Deleterious to Soil Health? Agronomy 2018, 8, 48. [CrossRef]

93. Yevdokimov, I.; Gattinger, A.; Buegger, F.; Munch, J.C.; Schloter, M. Changes in microbial community structure in soil as a result of different amounts of nitrogen fertilization. Biol. Fertil. Soils 2008, 44, 1103-1106. [CrossRef]

94. Saikia, R.; Sharma, S.; Thind, H.S.; Singh, Y. Tillage and residue management practices affect soil biological indicators in a rice-wheat cropping system in north-western India. Soil Use Manag. 2020, 36, 157-172. [CrossRef]

95. Olsen, J.K.; Lyons, D.J. Petiole sap nitrate is better than total nitrogen in dried leaf for indicating nitrogen status and yield responsiveness of capsicum in subtropical Australia. Aust. J. Exp. Agric. 1994, 34, 835-843. [CrossRef]

96. Chien, S.H.; Prochnow, L.I.; Cantarella, H. Recent developments of fertilizer production and use to improve nutrient efficiency and minimize environmental impacts. Adv. Agron. 2009, 102, 267-322.

97. De Pascale, S.; Maggio, A.; Barbieri, G. Soil salinization affects growth, yield and mineral composition of cauliflower and broccoli. Eur. J. Agron. 2005, 23, 254-264. [CrossRef]

98. Machado, R.; Serralheiro, R. Soil Salinity: Effect on Vegetable Crop Growth. Management Practices to Prevent and Mitigate Soil Salinization. Horticulturae 2017, 3, 30. [CrossRef]

99. Timsina, J. Can organic sources of nutrients increase crop yields to meet global food demand? Agronomy 2018, 8, 214. [CrossRef]

100. Sánchez-Navarro, V.; Zornoza, R.; Faz, Á.; Fernández, J.A. Comparison of soil organic carbon pools, microbial activity and crop yield and quality in two vegetable multiple cropping systems under mediterranean conditions. Sci. Hortic. (Amst.) 2020, 261, 109025. [CrossRef]

101. Voogt, W.; Balendonck, J.; Berkelmans, R.; Enthoven, N. Irrigation management in organic greenhouse: How to comply with sustainability goals. Acta Hortic. 2017, 1164, 273-288. [CrossRef]

(C) 2020 by the authors. Licensee MDPI, Basel, Switzerland. This article is an open access article distributed under the terms and conditions of the Creative Commons Attribution (CC BY) license (http://creativecommons.org/licenses/by/4.0/). 